\section{Simple method for separating platelets from red cells before enumeration with an electronic counter}

\author{
R. D. EASTHAM From the Department \\ Pathology, Frenchay Hospital, Bristol
}

A rapid method for counting platelets in whole blood has previously been described Eastham (1963). In this method, platelets in a sample of whole blood diluted with saline were separated without loss from the bulk of the red cells by means of centrifugation. Unfortunately $0.2 \mathrm{ml}$. of blood was required for each estimation, since the mass of red cells prevented settling and loss of platelets during centrifugation. Foss, Rosenlund, and Vik (1960) described a method for the separation of platelets from red cells without loss by means of simple sedimentation of red cells in a sample of blood diluted with sodium citrate solution, requiring $1 \mathrm{ml}$. of whole blood. A modification of this method is given here, which requires

Received for publication 13 March 1964

\section{Rapid method for counting reticulocytes-continued.}

counts may be insufficiently accurate in these cirumstances, and this defect can be removed by increasing the product $9 x$ by counting more cells. The number of cells to be counted can be calculated from equation 2 .

The optimum ratio of the areas of the two squares in the graticule has been considered by Woolf (1950). Any ratio may be used and if $a$ is this ratio, 9 for the Miller graticule, the standard error can be calculated from Woolf's equation, rearranged for ease of calculation thus:

$$
\mathrm{S}_{\mathrm{p}}=\sqrt{\frac{\mathrm{p}(1+\mathrm{ap})}{\mathrm{ax}}}
$$

Taking into account Woolf's argument and other considerations, the optimum ratio for a routine laboratory technique is considered to be $10: 1$, making 100 the number of cells to be counted. The Miller graticule was used because it is available commercially and the advantages of a $10: 1$ graticule over the Miller graticule are marginal.

\section{REFERENCES}

Brecher, G., and Schneiderman, M. (1950). Amer. J. clin. Path., 20, 1079.

Britton, C. J. C. (1963). In Whitby \& Britton's Disorders of the Blood, 9th ed., p. 69. Churchill, London.

Dacie, J. V., and Lewis, S. M. (1963). Practical Haematology, 3rd ed., p. 28. Ibid.

Woolf, B. (1950). Edinb. med. J., 57, 536. only $20 \mathrm{c} . \mathrm{mm}$. of blood and is therefore suitable for capillary collection from patients.

Red cells which are not aggregating into rouleaux would fall singly in plasma at a rate of $4 \mathrm{~mm}$./hour, if the rate of fall is calculated from the known dimensions of red cells and plasma. In saline, because of lower viscosity and lower density of saline as compared with plasma, red cells would sediment at $4 \mathrm{~mm}$./hour if the dilution of the blood sample is adequate to prevent frequent collisions between cells which produce surface charges on the cells (Elton and Hirschler, 1954). This rate can be observed experimentally. Red cells fall regularly without turbulence or production of eddy currents if Reynold's number for the system is less than 0.1 (Goldstein, 1938). In fact, the dimensions of red cells and saline are such that Reynold's number is less than $7 \times 10^{-4}$.

When platelets are introduced, it can be calculated that they sediment very much more slowly than red cells. They have a specific gravity of less than 1.045 (Morgan and Szafir, 1961) and the largest platelets have a volume of about $30 \mu^{3}$, the average platelet volume being $15 \mu^{3}$. In saline, these largest platelets would sediment at about $1 \mathrm{~mm}$./hour and the bulk of the platelets would sediment at less than $1 \mathrm{~mm}$. per hour, since the rate of fall is proportional to the square of the radius of the particle falling. Finally the Reynold's number for the system when platelets are considered is less than $5 \times 10^{-4}$ and therefore sedimentation is regular.

\section{METHOD}

Whole blood, 20 c.mm., is mixed with $2.5 \mathrm{ml}$. filtered saline with added E.D.T.A. in a siliconed test tube of internal diameter 10 to $15 \mathrm{~mm}$. Siliconing of the tubes is essential since it prevents eddy currents due to surface effects on the sedimenting cells. The tube is covered with a cap to prevent the entry of dust, and is allowed to stand for two to three hours at room temperature until at least $0.5 \mathrm{ml}$. of red-cell-poor, platelet-rich supernatant can be removed without disturbing the lower mass of sedimenting red cells. Using a Coulter electronic counter model A the supernatant fluid is diluted 50 -fold $(0.5 \mathrm{ml}$. made up to $25 \mathrm{ml}$. with saline), and counts are made of red cells + platelets and platelets only, at two settings, as previously described Eastham (1963).

After correction for coincidence, the whole blood platelet count $=$

$\frac{\text { corrected machine platelet count } \times 100}{8}$ per c.mm.

RESULTS

From a sample of E.D.T.A. blood 10 replicates of three different dilutions of blood in saline were allowed to sediment in siliconed tubes for two to three hours. From these dilutions, whole blood platelet counts were obtained and compared with platelet counts made using the method of Eastham (1963) on the original blood sample (Table I).

A series of counts were made on blood samples by the simple sedimentation method and by the centrifugation method Eastham (1963). Results are given in Table II. 
TABLE I

COMPARISON OF WHOLE BLOOD PLATELET COUNTS USING VARYING AMOUNTS OF BLOOD BY PROPOSED AND CENTRIFUGATION METHODS ${ }^{1}$

\begin{tabular}{|c|c|c|c|c|c|}
\hline $\begin{array}{l}\text { Whole } \\
\text { Blood }\end{array}$ & $\begin{array}{l}\text { Saline } \\
(\mathrm{ml} .)\end{array}$ & Replicates & $\begin{array}{l}\text { Mean } \\
\text { Whole } \\
\text { Blood } \\
\text { Platelets } \\
\text { (per c.mm. }\end{array}$ & I S.D. & $\begin{array}{l}\text { Coefficient } \\
\text { of } \\
\text { Variation } \\
(\%)\end{array}$ \\
\hline $\begin{array}{l}20 \mathrm{c} . \mathrm{mm} . \\
40 \mathrm{c} . \mathrm{mm} . \\
0.1 \mathrm{ml} .\end{array}$ & $\begin{array}{l}2 \cdot 5 \\
2 \cdot 5 \\
2 \cdot 5\end{array}$ & $\begin{array}{l}10 \\
10 \\
10\end{array}$ & $\begin{array}{l}207,440 \\
212,730 \\
219,730\end{array}$ & $\begin{array}{l}6,900 \\
8,500 \\
5,000\end{array}$ & $\begin{array}{l}3 \cdot 3 \\
4 \cdot 0 \\
2 \cdot 3\end{array}$ \\
\hline
\end{tabular}

\section{TABLE II}

COMPARISON OF 20 ROUTINE WHOLE BLOOD PLATELET COUNTS BY CENTRIFUGATION AND PROPOSED SEDIMENTATION METHODS

\begin{tabular}{|c|c|c|}
\hline Whole Blood Platelet $C$ & Counts per c.mm. & Percentage Difference \\
\hline $\begin{array}{l}\text { Centrifugation Method } \\
\text { (Eastham, 1963) }\end{array}$ & $\begin{array}{l}\text { Proposed Simple } \\
\text { Sedimentation } \\
\text { Method }\end{array}$ & Method \\
\hline
\end{tabular}

$\begin{array}{llr}119,540 & 126,120 & +5 \cdot 5 \\ 176,220 & 159,130 & -9 \cdot 7 \\ 181,160 & 163,250 & -9 \cdot 9 \\ 189,780 & 192,940 & +1 \cdot 7 \\ 196,660 & 194,420 & -1 \cdot 1 \\ 200,640 & 175,640 & -12 \cdot 5 \\ 203,620 & 209,100 & +2 \cdot 7 \\ 208,080 & 251,590 & +20 \cdot 9 \\ 211,060 & 197,670 & -6 \cdot 3 \\ 213,560 & 217,210 & +1 \cdot 7 \\ 221,440 & 216,120 & -2 \cdot 4 \\ 223,370 & 241,250 & -8 \cdot 0 \\ 229,250 & 213,530 & -6 \cdot 9 \\ 235,060 & 222,670 & -5 \cdot 3 \\ 243,110 & 225,750 & -3 \cdot 8 \\ 248,900 & 239,350 & -7 \cdot 8 \\ 253,960 & 234,060 & -4 \cdot 5 \\ 269,130 & 257,030 & -3 \cdot 8 \\ 295,120 & 282,810 & -10 \cdot 0 \\ 436,440 & 392,610 & \end{array}$

SUMMARY

A simple method for the separation of platelets from red cells without loss by sedimentation is described. The plate- let-rich, red-cell-poor supernatant fluid is suitable for an accurate whole blood platelet count using an electronic particle counter. Only $20 \mathrm{c} . \mathrm{mm}$. of blood is required for each count.

\section{REFERENCES}

Eastham, R. D. (1963). J. clin. Path., 16, 168.

Elton, G. A. H., and Hirschler, F. G. (1954). Brit. J. appl. Phys. suppl. 3, 560.

Foss, O. P., Rosenlund, B., and Vik, O. (1960). Nord. Med., 64, 1350 Goldstein, S. (1938). Modern Developments in Fluid Dynamics, p. 418. Oxford University Press, London.

Morgan, M. C., and Szafir, J. J. (1961). Blood, 18, 89.

\section{Estimation of true glucose in blood by the AutoAnalyser}

\section{MATTHEW DICK From the Central Middlesex Hospital, London}

The introduction of the new tubular flow cell has enforced changes in AutoAnalyser methods. This, with the new ' $C$ ' membrane, now permits estimation of glucose by a glucose oxidase method at a rate of 60 samples per hour and with a sample volume of about $0.1 \mathrm{ml}$.

The reagents are those of Discombe (1963) with a reduction in the concentration of o-dianisidine from $500 \mathrm{mg}$. per litre to $200 \mathrm{mg}$. per litre. All reagents must be filtered.

The flow diagram is altered as in Figure 1.

The principal advantages are the use of a single dialysis, greater economy in reagents, greater speed, and smaller samples. The sensitivity is increased to about 23 transmission lines for a $100 \mathrm{mg}$. \% standard.

\section{REFERENCE}

Discombe, G. (1963). J. clin. Path., 16, 170.

Received for publication 20 April 1964

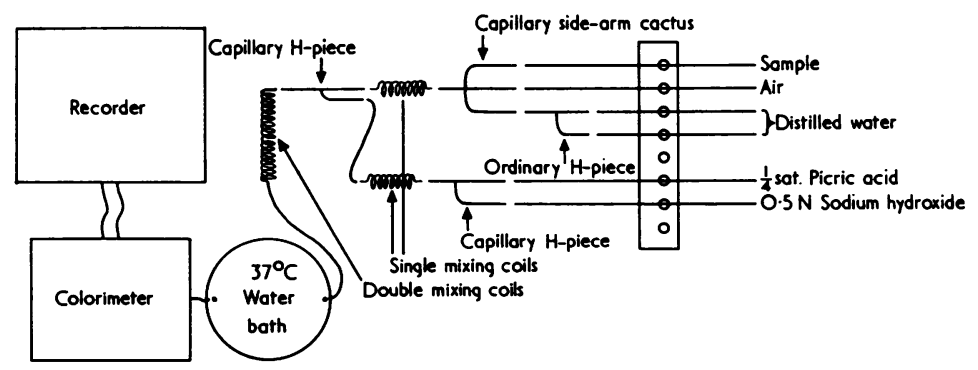

FIG. 1. The flow diagram for the AutoAnalyser as used in the present method. 